\title{
A Nation of One: A Critical Analysis of the Rise of the Notion of Ethnocultural Oneness in Twentieth-Century Korea
}

\author{
Josiah Gabriel Hunt \\ Adventist International Institute of Advanced Studies, United States \\ Email: huntj@aiias.edu
}

http://dx.doi.org/10.18415/ijmmu.v4i4.76

\begin{abstract}
This essay has been written to critically explore the societal idealization of oneness held among the Korean people. Particular emphasis is paid to scholarly works published between the years 2010 and 2016. The central finding procured by reviewing works meeting this study's inclusion criteria suggests that the notion of ethnocultural oneness is a modern myth structured along the political ideologies of the state. As such, attention is duly afforded to the historic origins of oneness and how this perception emerged in the twentieth century as a response to the period of Japanese colonization (1910-1945), the Korean War (1950-1953), and the years (1960-1988) in which Korea experienced rapid industrial development. It is assumed that the knowledge generated from this study may be used to (a) extend critical discourse on Korea's cultural history, (b) provide an alternative view on the formation of Korea's national identity, and (c) illuminate taken for granted perceptions that have been propagated among the people of Korea in the twentieth century as means to promote a sense of togetherness.
\end{abstract}

Keywords: Korea; Cultural history; National identity; Cultural history; Homogeneity; Ethnic nationalism

\section{Introduction}

The proverb, “모나면 정 맞는다" [The nail that sticks out gets hammered], reveals Korean society as being governed by principles of oneness and unity. In a way, Korea is a nation of one. By that I am referring to the collective perception shared among the people of Korea of being a society one in ancestry, blood, race, language, and culture (Chung, 2011; Landsman, Ham, \& Min, 2014; Shim \& Park, 2008; Shin, 2006). While this is a notion that can certainly be debated in a time in which Korea's demographic composition is rapidly changing, my focus centers not so much on whether this notion is true, but rather on the origin of this perception.

The primary aim of this essay on ethnocultural oneness is to critically assess and build upon the existent knowledge base concerning Korea's cultural history. Advancing a comprehensive understanding of a problem or contextual insight into a research query necessitates analysis of descriptive reports, empirical studies, and theoretical literature from a variety of sources including, but not limited to, conference programs, dissertations and theses, electronic libraries and databases, government records, professional journals, and official websites. While sources abound, those chosen are essentially 
determined by the clarity and specificity of the type of questions asked. In this theoretical report, I explore one central question: What are the historic origins of Korean ethnocultural oneness?

I performed an initial scan of literature for works related to cultural homogeneity in Korea to survey keywords frequently used. Articles accessed from the EBSCO HOST database yielded the following: cultural identity, ethnic nationalism, familism, hermit kingdom, Koreanness, Korean culture, national identity, racism, and traditional values. After identifying those applicable to the purpose of this review, varying combinations of keyword search were used to identify and obtain relevant publications from databases including Academic Search Complete, ERIC, Google Scholar, JSTOR Journal Archives, Primary Search, Proquest Open Access, and PsycARTICLES. Research studies and theoretical reviews were also located by searching through catalogues belonging to the following journals: Analysis from the East-West Center, Korea Journal, and Multicultural Education Review. The central finding garnered from reviewing seminal publications and works published between 2010-2016 suggests that the notion of Korean oneness is a modern myth structured along political ideologies of the state as a means to unite the people of Korea. The information that follows provides a critical analysis of the emergence of the notion of Korean oneness and its collective adoption as the national ethos during the twentieth century.

\section{A Nation of One}

During the Koguryo (고구료 [37 B.C.-668]), Paekche (백제[18 B.C.- 660]) and Silla (신라 [57 B.C.-935]) kingdoms - the Three Kingdoms (삼국시대) period in Korean history-Confucianism provided the matrix for culture formation and development (Joe, 2000). Described as an ancient tradition "encompass [ing] a broad array of moral, social, philosophical and religious ideas, values, and practices" (Littlejohn, 2011, p. xix), the tradition's tenets reflect Confucius' (551-479 B.C.) experiential desire as one orphaned during a period of constant warfare to create a peaceful, well-ordered society governed by virtue and benevolence (Rainey, 2010; Sun, 2013). Clark (2000) accordingly notes the tradition places considerable emphasis upon fostering a sense of harmony between the family, village, and state. As a historically Confucian society, the people of Korea value collectivism, familism, group belongingness, and interdependence (Bell, 2015; Shim, Kim, \& Martin, 2008). In turn, such values shape, harmonize, and affirm Korea's cultural identity by fostering a sense of Jeong (정) in the "we" relation (for more on Jeong, see Chung and Cho, n.d.; Son, 2014).

Adopting Confucianism as the nation's social ethos furthered Korea's cultural transformation into a relational society where self-identity became bound to, and determined by, self's relation to others. From a Confucian perspective, humans exist within an ecological web of interdependent experiences, events, and relations (Ames, 2010). Hence, the assertion that self has "meaning because others exist," illustrates the rendering of individual identity as being "inherently social - an integral part of the collective" (Shim et al., 2008, p. 44). While a commitment to the communal ethos underscores Confucian ethics, H. Lin (2011) positions the individual at the epicenter of all social relations; yet, not in such a manner as to assert one's rights, but to rather fulfill one's individual responsibilities. These responsibilities are essentially social: loyalty from servant to master, deference from younger to elder, difference between husband and wife, filial piety from child to parent, and trust between friend and friend (Haboush, 1991; Hsu, 1975; Littlejohn, 2011; Rainey, 2010). With such relations as a point of reference, Clark (2000) writes, "Throughout a person's life, he or she is always defined in relation to everyone else" (p. 31). Such patterns of relating, while creating unique configurations of roles and relations dynamic in nature, forge a sense of interconnectedness and solidarity among the people of Korea expressed as "Uri" (우리)—a we-relation that is not to be changed, but accepted and fulfilled (Joe, 2000; Shim et al., 2008). 


\section{(De)Constructing Hegemonic}

\section{Understandings of Identity}

Of all the characteristics that define Koreanness, the ethnically based blood-lineage relation appears to be paramount. Supporting this notion are the works of authors K. Han (2007), C. Lee (2014), and Seol (2014), which include sections that critically assess historically constructed views of Korean identity. These authors suggest the identification of a person as "Korean" is ultimately determined by "ethnizenship" as opposed to citizenship. While the term's original coinage refers to an "external quasicitizenship" granted to noncitizens and cultural others based on a "perceived common ethnicity" (Bauböck, 2007, p. 2396), ethnizenship can also be seen as a form of nationalism that associates holders of specific ethnicities with the possessors or definers of the national identity-note: Bell (2015) refers to this as "cultural nationalism" (p. 44). It then becomes apparent that Korea, a country that prides itself on being culturally and ethnically homogenous (Kang, 2010; Seol, 2014), practices a form of ethnizenship where the possession of the right kind of blood acts as the primary determinant of Koreanness.

While four major blood groupings are thought to exist (i.e., $\mathrm{A}, \mathrm{B}, \mathrm{AB}, \mathrm{O}$ ), a fifth is found in the notion of there being "Korean" blood. A statement in Ahn's (2014) words rearticulating the mixed-race era of Korean globalization provides insight into the blood principle: 'If someone is a 'full-blood,' she/he is considered a 'full' Korean, whereas 'mixed-blood' is located outside the imagined boundary of the (ethnic) nation" (p. 406). In investigating the question, "What does it mean to be Korean?" the literary undercurrent consistently ebbs back to blood lineage and ancestral descent. Examples of this are seen in statements such as (a) "Koreans are one, linked in blood and culture" (Chung, 2011, p. 10); (b) "Koreanness is ... transferred in the blood" (Gage, 2007, p. 55); (c) "Korea . . adheres to a jus sanguinis (right of blood) principle of nationality" (Seol, 2014, p. 138, original emphasis); and (d) "the Korean notion of nationhood is often typified by a strong ethnic identity based on a myth of common descent" (C. Lee, 2014, p. 95). Though the notions of "pure-blood" [순혈] and ethnic homogeneity remain, scholars in the Korean academia are increasingly challenging this assumption.

In recent years, numerous works have been published identifying the ideological doctrine of cultural and ethnic oneness as a myth (see e.g., Ahn, 2013; K. Han, 2007; J. Lee, 2014). In one theoretical work comparing the Korean identity to that of the German, authors Kim and Cho (2015) make the assertion that both nations bear the similarities of having constructed cultural "tradition[s] based on the myth of the 'single ethnicity,' 'pure blood,' [and] 'monoculture'" (100). Like statements abound in Ahn's (2013) dissertation on the visualization of race and Koreanness in contemporary Korea. One of the central arguments Ahn (2013) presents is that "the term monoracial Korea does not necessarily refer to a social fact, but rather ... [to] a hegemonic understanding of a modern Korea" (p. 44, emphasis added). The term "modern" is emphasized for the coming together of Koreans as a united people one in ancestry, culture, language, and blood - though purported to be a tradition five millennia in the making (see e.g., Oh, 2013) - is increasingly framed within the literature as a modern occurrence that contradicts historical realities.

A number of contradictions exist in the literature concerning Korea's history of oneness. For example, Oh et al. (2012) describe Korea as historically being a homogenous society consisting of $99.9 \%$ ethnic Koreans. The writings of Kang (2010) and Oh (2013) include statements that emphasize the notion of Korea having unique national and cultural heritages that have for millennia created a sense of oneness, peace, and harmony. Others write of "immigration and emigration . . . [as] relatively new phenomena" (Kong, Yoon, \& Yu, 2010, p. 252) as a means of affirming the historical authenticity of Korean homogeneity. A number of statements in the seminal works of K. Han (2007) and Joe (2000), however, directly contradict the above notions. For instance, in examining naturalization policies and practices prior to the emergence of Korea's single-race ideology, K. Han (2007) declares that during the Goryeo 
(고려 [918-1392]) and Joseon (조선 [1392-1910]) dynastic periods, Koreans did not consider themselves to be ethnically homogenous nor did they believe in a common biological ancestor. K. Han (2007) also portrays the Joseon government as having been welcoming to foreign immigrants, helping such individuals "settle ... and assimilate themselves to a Korean . . way of life" (p. 21) - a notion in stark contrast with Kong et al.'s (2010) above statement on immigration, emigration, and Korean homogeneity. Furthermore, Joe's (2000) statement made in reference to the Three Kingdoms that "the ultimate goal of each kingdom was to conquer the other two, thus acquiring land and slaves as a labor force" (p. 3), is at discord with the positive idealization of Korean history seen in the publications of Kang (2010) and Oh (2013).

Peace and harmony, while having performed as ideological foundations in Korea's cultural development, were not synonymous with equality. The notion of people being born equal or becoming equal throughout the course of life is foreign to Confucian ethics (Clark, 2000). Confucius (2008) taught that "a ruler [is to] be a ruler, a subject a subject, a father a father, and a son a son" (p. 46). Hence, while often idealized as a harmonious society, the harmony that existed in Korea was premised upon inequality.

Korea has historically been a nation of strict divides. During the Goryeo and Joseon dynasties, four class divisions existed: Yangban (양반 [ruling]), Chungin (중인 [middle]), Sangmin (상민 [commoner]), and Ch'onmin (천민 [lowborn/slave]). While these classes differed with respect to status, birth (i.e., viewed as divine providence), education, opportunity, and size-the Ch'onmin being the largest in number (Joe, 2000) - the insistence of a tradition of cultural oneness remains prevalent in Korean thought. Understanding why this is so necessitates considering the events that have contributed to the idealization of ethnocultural oneness in twentieth century Korea.

As a nation that experienced the traumatic events of a civil war (i.e., the Korean War [19501953]) that cost the lives of more than 2 million Koreans, and a sustained marginalization of their national identity and culture by an oppressive colonial power (i.e., Japan [1910-1945]), the historical contingencies endured are prominent factors that have advanced the construction of a uniquely Korean national identity (Clark, 2000; Seow, 2013). In a very real sense, Korea's ethnically based cultural oneness is a product of the 20th century. In discussing the ideological construct of Danilminjok (단일민족)—a term used to express the idea of the Korean nation consisting of one people-Chung (2011) remarks that it "became prominent before and during Japanese occupation . . . as a mechanism of resisting the Japanese regime" (10). While oneness in blood, language, and culture are often cited as key features of Koreanness (see e.g., Crane, 1967; Landsman et al., 2014; Shin, 2006), the commonalities shared are useful only to the extent to which they create a sense of difference between Koreans and racial or cultural others (M. Oh, 2013). That "other" finds its highest manifestation in Korea's second most proximal neighbor-Japan.

\section{The Colonial Years}

While history bears testament to repeated incursions and acts of Japanese aggression (see e.g., W. Han, 1988; Joe, 2000), only in the twentieth century did Japan succeed in bringing Korea under its colonial domain. For a period of 35 years (1910-1945), Japan ruthlessly exploited, dominated, and subjugated Koreans economically, politically, socially, physically (e.g., comfort women), and culturally (Ha, 2013; H. Y., Lee 2013). During these years Koreans were forced to (a) pay respect to Japanese national heroes, (b) use the Japanese language instead of Korean, (c) adopt Japanese names, and (d) identify themselves as Japanese (Chung 2011; Clark, 2000; Lee, Han, \& McKerrow, 2010; Shim et al., 2008). Weiner (1994) assesses Japan's policy of assimilation as “demand[ing] no less than absolute acculturation. . . [-] the complete abandonment of an independent Korean identity and its replacement by Japanese institutions and forms of behavior" (5). In the seminal publications of Joe (2000) and Osgood 
(1951) on Korea's cultural history, it is reported that those who refused (be it through passive resistance, peaceful demonstration, or active revolt) were whipped; assaulted with clubs, swords, bayonets, and hooks that tore chunks out of human flesh; seared with hot irons; had their genitals crushed and mutilated; stripped naked and beaten publicly (mostly women and school girls); imprisoned without fair trial; and executed by firing squads. Commenting on this dark period in Korean history, Seow (2013) makes the following observation:

Under Japan's iron-fisted rule, Koreans endured severe living conditions. . . . They struggled to regain their state autonomy and dignity. Their common desire to restore their cultural, economic and political identity and to expel the Japanese from their homeland was seen in their constant resistance to Japanese occupation . . . and that developed into sustained nationalism. (p. 5)

While horrid, the atrocities committed during the colonial years played a pivotal role in bringing the Korean people together and furthering the construction of a unified conception of Korean identity (M. Oh, 2013).

Notwithstanding the existence of a common language, a Yangban-controlled bureaucracy, a system of strict class divisions, a historical record of five millennia, and a set of social principles grounded in Confucian ethics (ie., the $O$-Ryun [오륜] relation), works discussing Korea's cultural history often date the nation's birth as a united people to (a) the colonial period, or (b) the years following the Korean War (see e.g., Ahn, 2013; K. Han, 2007; Kim, 2015; H. Y. Lee, 2013; J. Lee, 2014; M. Oh, 2013). For example, in commenting on the period before the colonial years, Osgood (1951) remarks, "Many Korean customs and institutions were by then not only medieval in character but were also functionally degenerate" (p. 277); H. Y. Lee (2013) further questions "whether Koreans developed any notion of a national identity before Japanese colonization" (6); and K. Han (2007) asserts that "the idea of ethnic homogeneity was developed ... during the colonial period as a countermeasure against the Japanese propagandist notion of naisen ittai ('Korea and Japan are one and the same')" (p. 23). If true, Korean nationalism based on the ideology of ethnocultural oneness would then be a figment imagined, constructed, and intentionally devised (see H. Y. Lee, 2013).

The colonial years mark a critical period of transformation in Korean history and identity. No longer were they a divided people in a Yangban-led bureaucracy, but an oppressed people united in a struggle against a foreign oppressor. "Man-se!" (만세 [Viva]) was the oft heard cry as "coolies, nobles, scholars and preachers, children and aged, male and female, walked side by side" in protest of their nation's annexation to imperial Japan (Osgood, 1951, p. 286). Undoubtedly, such collective acts of patriotism were not without effect in bonding the oppressed together. What emerged was a collective "Uri" identity emphasizing our culture, our destiny, our language, our people, and our nation (Joe, 2000; H. Y. Lee, 2013). J. Lee (2014) writes, "In order for nationalism to function, a people must be fully committed to an ideal to the extent that it operates as an everyday reality" (p. 11). During the colonial years, freedom from the quotidian reminders of Japanese rule furthered the ideological commitment to a revamped nationalism reaffirming Korea's cultural heritage and national identity (Joe, 2000; J. Lee, 2014). It was only at this time that Tan-gun (단군) — son of the celestial being Hwan-ung (환웅)— transformed from being the mythic founder and political leader of the first Korean empire (Ko-Joseon [고조선]) to the progenitor of the Korean race (K. Han, 2007). The newfound nationalism, in conjunction with the conceptualization of the Korean people as biological descendents of Tan-gun (for more on Tangun, see Crane, 1967; W. Han, 1988; Joe, 1997, 2000; Osgood, 1951), further embedded the notion of oneness in blood and culture among the Korean people. 


\section{After Liberation}

While the unconditional surrender of the Japanese on August 15, 1945 liberated Korea from colonial rule, the presence of Russian soldiers in the North and the American military in the South led to the division of the nation along the thirty-eighth parallel (W. Han, 1988; Osgood, 1951). Under the trusteeship system, Korea (North and South) was to be governed under the trust of Britain, China, the Soviet Union, and the United States of America until the nation became stable enough to create an independent Korean national government (W. Han, 1988; Shin, 2005). Though stipulated to be a temporary arrangement (Barry 2012), widespread resentment arose in response to the nation's division and governance by foreign others. W. Han (1988) remarks, after years of "longing and fighting for independence, . . . even benevolent foreign rule" seemed intolerable (p. 500). As a nation dating its unification to the seventh century Three Kingdoms period by Silla (Paik, 2014), the externally imposed division furthered Koreans' desire for reconciliation as a nation belonging to one people. This is evinced in former president Rhee Seung-man's (이승만 [1948-1960]) declaration: "The first task for the Korean people [is] to unify the country and terminate the American and Russian military governments as quickly as possible" (W. Han, 1988, p. 499). Given the vested political interests of the foreign powers in both North and South Korea (Paik, 2014), the continued division of the nation seemed imminent as peaceful agreement between the communist North and democratic South could not be reached. To the North Korean regime, unification by military conquest then became an unwanted, but necessary, means of reconciliation (Drennan, 2003).

Framed as a war of liberation against opposing ideologies, the 1950-1953 war was not so much a civil one among Koreans as it was a war founded upon, and furthered by, the political interests of the Mao, Stalin, and Truman administrations (Barry, 2012; Campbell, 2014; Cha, 2012; Suh, 2010). Viewing the Korean War as a civil war among Koreans, as does Drennan (2003), ignores the fact that foreign governments provided the arms, finance, military personnel, and strategic support for the war's continuance. Depending on the party writing history, the positioning of the victim-aggressor relationship promulgated between South and North Korea ultimately determines the manner in which foreign involvement is viewed. In South Korea for example, Jeon (2010) notes that the United States has the "false image" of having rescued them from the "vicious attacks" initiated by the communist North (p. 624); whereas H. J. Lee (2010) cites a North Korean informant as having said, "'In North Korea we learned that South Korea started the Korean war"' (p. 50; see also Cha, 2012). Regardless of how the story is told, the 1950-1953 Korean War occurred as an unintended consequence of the (a) sustained presence of American and Soviet troops after liberalization in 1945, and (b) aforementioned nations' respective fears of the Sovietization and Americanization of the peninsula. The 1953 armistice thus signals not so much a shared desire for peace, but rather the reaching of a stalemate stemming from the communist North's and democratic South's failure to unite the people of Korea as one nation by military conquest and peaceful negotiation (Paik, 2013).

\section{The Developmental Period}

While the colonial years furthered the belief in oneness in blood and culture, and the War of 1950-1953 the desire for unification, the developmental period (1960-1988) advanced the notion of South Korea being an ethnically homogenous nation-state. Prior to the peninsula's partitioning into North and South divides in 1948, distinctive North and South Korean identities were non-existent (Oh, 2013). The Korean War, however, necessitated a revision of the once shared identity construct that emerged "out of, and in opposition to, Japanese colonial rule" (Suh, 2010, p. 505). In examining the reconfiguration of national identity among South Koreans from 1960 to the present age, Ahn (2013) contends that the ideological construction of a monoracial Korea was the collusive work of president Park Chung-hee's (박정희 [1961-1979]) authoritarian regime and a propagandistic broadcasting system. Ethnic nationalism - while used to combat the influences of western civilization, fight colonial indoctrination, 
and "mend. . . the psychological wounds of the Korean war and the subsequent division of [the] nation" (Oh et al., 2012, p. 22) — was in the years after the Korean War a force harnessed for modernization.

The developmental period was a time in which numerous initiatives, policies, programs, and slogans were devised to reinforce the Danilminjok ideology. Examples of policies include the (a) five-year Cultural Renaissance Plan of 1973 designed to "foster a sense of national identity . . . among the citizenry" (H. S. Kim, 2015, p. 113); (b) 1973 Saemaul (새마을 [New Village]) initiative and its use of traditional ethics (e.g., cooperation, frugality) to further national development (Ahn, 2013; Clark, 2000); (c) Third National Curriculum (1973-1981) which bolstered national consciousness (H. S. Kim, 2015); and (d) Charter of National Education which sought to create a new national culture and identity based on tradition, progress, and harmonious relations (H. S. Kim, 2015). Chung (2011) writes that the spirit of national oneness, as expressed in the Danilminjok ideology, "helped Koreans overcome national hardships" (10). The use of political slogans such as "뭉치면산다, 흩어지면 죽는다" (Together we live, divided we perish [Rhee administration]), “재건합시다" (Let's rebuild [Park administration]), “세계화 합시다" (Let's work for globalization [Kim Yong Sam administration-김영삼, 1993-1998]), and "함께 가자! 세계로!" (Let's go together to the new world), were instrumental in bringing the people of Korea together in a time when national development was most needed (Shim et al., 2008). It would then seem that Danilminjok - a culturally, linguistically, ancestrally, and ethnically based societal relation — was propagated as being indispensable to Korea's postwar development and modernization.

The unprecedented industrial and economic growth experienced during Korea's developmental years fostered in its people a sense of confidence, distinction, pride, and self-respect as a nation (K. Han, 2007; I. Lee, 2011). In the seminal work, Asian Power and Politics: The Cultural Dimensions of Authority, Pye (1985) remarks, "Having suffered as much as they did, but in the end surviving, the victorious Koreans, both government officials and civilians, soon came to see themselves as exceptional and destined for great things" (p. 218). No longer were they to view themselves as a downcast people slave to poverty and colonial rule, but as victors who possessed cultural and ancestral heritages that were distinctly Korean (H. S., Kim 2015). Pye (1985) thus observes that the strength of the Korean people lies in their "tenacious sense of solidarity and national pride" (p. 227). This sense of solidarity has within the twentieth century shifted from being a response to colonization to a product of 우리 나라의 [our nation's] collective successes.

\section{Conclusion}

The works included in the above discussion identified shifts in identity among the people of Korea during the colonial, liberalization, and modernization periods. It should be noted that modern Korea, while having the appearance of a Confucian society, may in truth be a kind of hybrid society. In the article "Reconciling Confucianism and Nationalism," Bell (2015) writes about a concept referred to as "Confucian universalism." Essentially, Confucian universalism posits "the only relevant criterion for admittance to [a] 'Confucian nation' ... [to be] commitment to Confucian values" (p. 45). While stated differently, the above notion finds credence in an assertion made by K. Han (2007): "The Joseon government was ready to help foreign immigrants settle in Korea and assimilate themselves to a Korean (namely 'civilized') way of life, but was not tolerant of those who continued to keep their foreign (therefore 'uncivilized') ways" (p. 21). Should Bell's (2015) and K. Han's (2007) statements be true, ancestry, ethnicity, language, and nationality could then be implicated as being inconsequential to membership in Confucian societies. In addition to this, Bell (2015) makes a poignant assertion: "Confucian nationalism - a commitment to Confucian values and an aspiration to a nation-state that expresses those values - is radically at odds with ethnic and racial forms of nationalism" (p. 45). This notion is in direct opposition with twentieth century Korea's insistence on blood, ancestry, and ethnicity being the defining characteristics of Koreanness (see e.g., Chung, 2011; Seol \& Seo, 2014). "Despite the actual hybridity of Korean ethnicity as a result of countless foreign invasions and cross-border population 
movements in the pre-modern era" (Seol \& Seo, 2014, p. 12), the ethnically based blood-lineage ideology remains entrenched in Korean thought. As the writings of Ahn (2013), K. Han (2007), H. S. Kim (2015), H. Y. Lee (2013), J. Lee (2014), and Oh (2013) prove to be highly persuasive, the possibility of ethnocultural homogeneity being a myth structured according to the political and cultural ideologies of the state to create a unified national identity seems plausible. In this way, unity in identity may not be based on an actual reality, but rather on a cognitive perception among the Korean people of reality as being shared.

While having a common heritage positively affirms Korea's cultural and historical identity, the historically developed concept of Koreanness leaves little room for cultural or ethnic heterogeneity. In a very real sense, Korean nationalism and identity are "exclusive and closed" (Yoon, Song, \& Bae, 2008, p. 2 ). Though the promotion of the belief in ethnocultural oneness may have had its place in twentieth century Korea, it may be an anachronous ideal if retained in present-day Korea's multicultural society.

Whether acknowledged or denied, the face of Korea has changed; yet that which begs question concerns the heart. It is true that the ideological doctine of ethnocultural oneness played an indispensible role in helping Koreans maintain a sense of identity during the colonial years; it cannot be denied that embracing unity and togetherness furthered national development in the years after the traumatic Korean War; but is the ethnocultural oneness ideal beneficial for our time? The words of an ancient king come to mind: "To everything there is a time and a season" (Ecclesiastes 3:1). What would be the effect of continuing to hold on to the doctrine of ethnocultural oneness in a time in which it no longer reflects Korea's social reality? If this ideal remains, how might it color the lived experiences of Korea's ethnically and culturally diverse populace? In truth, the twentieth century idealizaiton of oneness in lineage, race, and language as entry requisites to "Uri"-if it remains - will not be without effect in our time.

\section{References}

Ahn, J. (2013). Visualizing race: Neoliberal multiculturalism and the struggle for Koreanness in contemporary South Korean television (Unpublished doctoral dissertation). The University of Texas at Austin.

Ahn, J. (2014). Rearticulating black mixed-race in the era of globalization: Hines Ward and the struggle for Koreanness in contemporary South Korean media. Cultural Studies, 28(3), 391-417. doi:10.1080/09502386.2013.840665.

Ames, R. (2010). Confucian role ethics: A vocabulary. Sha Tin, Hong Kong: The Chinese University Press. Barry, Mark. 2012. The U.S. and the 1945 division of Korea: Mismanaging the "big decisions." International Journal on World Peace, 29(4), 37-59.

Bauböck, R. (2007). Stakeholder citizenship and transnational political participation: A normative evaluation of external voting. Fordham Law Review, 75(5), 2394-2447.

Bell, D. (2015). Reconciling Confucianism and nationalism. Journal of Chinese Philosophy, 41(1-2), 3354.

Campbell, J. (2014). The wrong war: The Soviets and the Korean War, 1945-1953. International Social Science Review, 88(3), 1-29.

Cha, V. (2012). The impossible state: North Korea, past and future. New York, NY: HarperCollins. 
Chung, C., \& Cho, S. (n.d). Significance of "Jeong" in Korean culture and psychotherapy. Retrieved from http://www.prcp.org/publications/

sig.pdf

Chung, J. (2011). The (dis)connection between policy and practice: Primary English education in South Korea (Doctoral dissertation). Retrieved from ProQuest Dissertations and Theses. (Accession Order No. 3484356)

Clark, D. (2000). Culture and customs of Korea. Westport, CT: Greenwood.

Confucius. (2008). The Analects (Raymond Dawson, Trans.). Oxford, NY: Oxford.

Crane, P. (1967). Korean patterns. Seoul, Korea: Hollym.

De Mente, B. (1998). NTC's dictionary of Korea's business and cultural code words. Singapore: McGraw Hill.

Drennan, W. (2003). North Korea's non-military threats. East Asia: An International Quarterly, 20(2), 48-59.

Gage, S. (2007). Pure mixed blood: The multiple identities of Ameriasians in South Korea (Doctoral dissertation). Retrieved from ProQuest Dissertations and Theses. (Accession Order No. 3253643)

Ha, Y. (2013). Colonial rule and social change in Korea: The paradox of the colonial control. In Colonial rule and social change in Korea: 1910-1945, eds. Hong Yung Lee, Yong-Chool Ha, \& Clark Sorensen, 39-75. Seattle, WA: University of Washington Press.

Haboush, J. (1991). The confucianization of Korean society. In The East Asian region: Confucian heritage and its modern adaptation, ed. Gilbert Rozman, 84-110. Princeton, NJ: Princeton.

Han, K. (2007). The archeology of the ethnically homogenous nation-state and multiculturalism in Korea. Korea Journal, 47 (4): 8-31. Retrieved from https://www.ekoreajournal.net/issue/index $2 . h t m ? I d x=$ 419\#.

Han, W. (1988). The history of Korea. Honolulu, HI: University of Hawaii Press.

Hsu, L. (1975). The political philosophy of Confucianism: An interpretation of the social and political ideas of Confucius, his forerunners, and his early disciples. London, UK: Curzon Press.

Jeon, S. (2010). War trauma, memories, and truths: Representations of the Korean War in Pak Wan-so's writings and in "still presents past." Critical Asian Studies, 42(4), 623-651. doi:10.1080/14672715.2010.515390

Joe, W. (1997). Traditional Korea a cultural history: A history of Korean Civilization. Elizabeth, NJ: Wallym.

Joe, W. (2000). A cultural history of modern Korea: A history of Korean Civilization. Elizabeth, NJ: Hollym.

Kang, S. (2010). Multicultural education and the rights to education of migrant children in South Korea. Educational Review, 62(3), 287-300. doi:10.1080/00131911.2010.503599. 
Kim, H., \& Cho, C. (2015). Comparative analysis of multi-cultural situations between Germany and Korea-Focusing on multicultural backgrounds, characteristics and policies for social integration. Advanced Science and Technology Letters: Art, Culture, Game, Graphics, Broadcasting and Digital Contents, 87, 100-107. doi:10.14257/astl.2015.87.21.

Kim, H. (2015). National identity discourses in visual culture and art education. Korea Journal, 55(1), $112-137$.

Kong, D., Yoon, K., \& Yu, S. (2010). The social dimensions of immigration in Korea. Journal of Contemporary Asia, 40(2), 252-274. doi:10.1080/00472331003600473.

Landsman, G., Ham, J., \& Min, H. (2014). Multiculturalism in Korea and differing views of adaption based on foreign interaction with Korean culture. Advanced Science and Technology Letters, 71, 145148. Retrieved from http://onlinepresent.org/proceedings/vol71_2014/34.pdf

Lee, C. (2014). How can you say you're Korean? Law, governmentality and national membership in South Korea. In South Korea in transition: Politics and culture of citizenship, ed. Kyung-Sup Chang, 93-110. New York, NY: Routledge.

Lee, H. J. (2010). Remembering and forgetting the Korean war in the Republic of Korea. Suomen Antropologi: Journal of the Finnish Anthropological Society, 35(2), 48-55.

Lee, H. Y. (2013). Introduction: A critique of colonial modernity. In Colonial rule and social change in Korea: 1910-1945, eds. Hong Yung Lee, Yong-Chool Ha, and Clark Sorensen, 3-38. Seattle, WA: University of Washington press.

Lee, I. (2011). Teaching how to discriminate: Globalization, prejudice, and textbooks. Teacher Education Quarterly, 38(1), 47-63.

Lee, J.. (2014). Legacies of Japanese colonialism in the rhetorical constitution of South Korean national identity. National Identities, 16(1), 1-13. doi:org/10.1080/14608944.2013.843516.

Lee, J., Han, M., \& McKerrow, R. (2010). English or perish: How contemporary South Korea received, accommodated, and internalized English and American modernity. Language and Intercultural Communication, 10(4), 337-357. doi:10.1080/14708477.2010.497555.

Lin, H. (2011). Traditional Confucianism and its contemporary relevance. Asian Philosophy, 21(4), 437445. doi:10.1080/09552367.2011.635896.

Littlejohn, R. (2011). Confucianism: An introduction. New York, NY: I.B. Tauris.

Oh, J., Kang, D., Shin, J., Lee, S. L., Lee., S. B., \& Chung, K (2012). Migration profile of the Republic of Korea. Retrieved from http://publications.iom. int/bookstore/free/MP_Korea.pdf.

Oh, M. (2013). "Hope for the win and hope for the defeat": Constructions of South Korean identity and the 2010 FIFA World Cup. Soccer \& Society, 14(5), 670-683. doi:10.1080/14660970.2013.792485.

Osgood, C. (1951). The Koreans and their culture. New York, NY: Ronald Press Company.

Paik, N. (2014). The "third-party" in inter-Korean relations and its potential contribution to modern Asian thought. Inter-Asia Cultural Studies, 15(1), 8-16. doi:10.1080/14649373.2014.871772. 
Pye, L. (1985). Asian power and politics: The cultural dimensions of authority. Cambridge, MA: The Belknap Press of Harvard University Press.

Rainey, L. (2010). Confucius \& Confucianism: The essentials. Malden, MA: Wiley-Blackwell.

Seol, D. (2014). The citizenship of foreign workers: Stratified formation, fragmented evolution. In South Korea in transition: Politics and culture of citizenship, ed. Kyung-Sup Chang, 131-145. New York, NY: Routledge.

Seol, D., \& Seo, J. (2014). Dynamics of ethnic nationalism and hierarchical nationhood: Korean nation and its otherness since the late 1980s. Korea Journal, 54(2), 5-33.

Seow, J. (2013). Pride of the people: South Korea and Korean nationalism. Retrieved from http://www.isis.org.my/files/IF_2013/IF8/IF8_I2.pdf

Shim, D., \& Park, J. (2008). The language politics of "English fever" in South Korea. Korea Journal, 48(2), 136-159.

Shim, Y., Kim, M., \& Martin, J. (2008). Changing Korea: Understanding culture and communication. New York, NY: Peter Lang.

Shin, G. (2005). Asianism in Korean politics and identity. Inter-Asia Cultural Studies, 6(4), 616-630. doi:10.1080/14649370500316992.

Shin, G. (2006). Ethnic nationalism in Korea. Stanford, CA: Stanford University Press.

Son, A. (2014). Jeong as the paradigmatic embodiment of compassion (hesed): A critical examination of disparate and dispositional Jeong. Pastoral Psychology, 63(5-6), 735-747. doi:10.1007/s11089-0140611-7.

Suh, J. (2010). Truth and reconciliation in South Korea: Confronting war, colonialism, and intervention in the Asia Pacific. Critical Asian Studies, 42(4), 503-524. doi:10.1080/14672715.2010.515386.

Sun, A. (2013). Confucianism as a world religion: Contested histories and contemporary realities. Princeton, NJ: Princeton University Press.

Weiner, M. (1994). Race and migration in imperial Japan. New York: Routledge.

\section{Copyrights}

Copyright for this article is retained by the author(s), with first publication rights granted to the journal.

This is an open-access article distributed under the terms and conditions of the Creative Commons Attribution license (http://creativecommons.org/licenses/by/4.0/). 